\section{UniBase: A Universal Database to View Images and Trace Pedigrees and Characteristics of Progenies}

Shahrokh Khanizadeh ${ }^{1}$

Agriculture and Agri-Food Canada, Horticultural Research and Development Centre, 430 Gouin Blvd., St-Jean-sur-Richelieu, QC, Canada J3B 3E6

Jamshid Ghavami ${ }^{2}$

Group Percan Inc., 641 A, Chemin Grand-Côte, Boisbriand, Québec, Canada J7E $4 H 4$

Abstract. UniBase is a Windows-based (95, 98, NT, 2000, or XP) user-friendly software package that was developed for those who are interested in creating their own instant databases, add information to an existing databases or import data and images from Excel in a choice of languages. The software is very useful for germplasm inventory (fruit crops, vegetables, ornamentals, agronomic crops, weeds, chemicals, insects, pests, animals, etc.) and can be used in any breeding program (animal, horticulture, agronomy, etc.) to trace pedigrees and view images and characteristics of progenies. The database can be searched using various criteria and the use of several operators. An unlimited number of images can be stored for each entry and several graphic formats including BMP, JPEG, GIF, TIFF, etc., can be used. Additional information on UniBase and available data and images can be obtained from the authors.

Plant and animal breeders are often interested to study and follow the pedigree of progenies and lines that have potential as parents in plant and animal improvement. Tracing and drawing pedigrees have generally been performed manually, which is both laborious and time-consuming. Furthermore, it is more interesting to trace pedigrees while looking at the images and characteristics of selected lines. Breeders have the opportunity to implement a wide range of microcomputer software programs, such as those that analyze linkages and mutation frequencies (St. John et al., 1983), structures and genetic variations of populations (Dowling and Moore, 1984), genotype $\times$ environment interactions (Kang, 1985), and generation means ( $\mathrm{Ng}, 1990)$, as well as those for record keeping and progeny evaluations (Bassi et al., 1990; Khanizadeh, 1990; Khanizadeh and Fanous, 1992; Khanizadeh and Prasher, 1997; Khanizadeh et al., 2000) to improve efficiency in breeding programs. However, most of these software programs are specific and do not allow the users to add a new database, change field names, import data and images, or enter the data in a chosen language.

This report describes a major modification that has been done to the previously released software (Khanizadeh, 1990; Khanizadeh and Prasher, 1997) based on the suggestions and recommendations received from the users since 1990 (Table 1).

Received for publication 17 Jan. 2003. Accepted for publication 9 Oct. 2003. Agriculture and Agri-Food publication 9 Oct. 2003.
Canada contribution

${ }^{1}$ Research scientist and adjunct professor, breeder, physiologist, and statistician.

\section{Description}

UniBase is a Windows-based $(95,98$, NT, 2000 , or XP) user-friendly software package that was developed for those who are interested in creating their own instant database. The program is partly derived from the software package Pedigree, which was developed by S. Khanizadeh in 1997. UniBase allows the user to create a new database by importing
Table 1. Feature comparison of UniBase vs. Pedigree.

\begin{tabular}{|c|c|c|}
\hline Feature & Unibase & Pedigree \\
\hline$\overline{\text { Data and images included }}$ & Yes & No \\
\hline Make new databases & Yes & No \\
\hline $\begin{array}{l}\text { Change field name using } \\
\text { any language }\end{array}$ & Yes & No \\
\hline $\begin{array}{l}\text { Scan and bring images } \\
\text { into database }\end{array}$ & Yes & No \\
\hline Draw pedigree & Yes & Yes \\
\hline Magnify images & Yes & No \\
\hline $\begin{array}{l}\text { Accept common image } \\
\text { formats gif, jpg, bmp }\end{array}$ & Yes & Yes \\
\hline $\begin{array}{l}\text { Search/multiple search } \\
\text { for items }\end{array}$ & Yes & Yes \\
\hline $\begin{array}{l}\text { Win } 95,98, \mathrm{NT} \text {, and XP } \\
\text { compatible }\end{array}$ & Yes & Yes \\
\hline Import data from Excel & Yes & No \\
\hline Import images & Yes & No \\
\hline $\begin{array}{l}\text { The professional version } \\
\text { can be redistributed with } \\
\text { user's own logo and data }\end{array}$ & Yes & No \\
\hline $\begin{array}{l}\text { The administrator can make } \\
\text { the data read only } \\
\text { or give a user password }\end{array}$ & Yes & No \\
\hline $\begin{array}{l}\text { Multiple users can access } \\
\text { the data simultaneously }\end{array}$ & Yes & Yes \\
\hline
\end{tabular}

existing data and images. Field names can easily be changed using any installed language, images and pedigrees of any horticultural crop can be viewed instantly using the pull down menu (Fig. 1), and password protection can be added to make the database a read-only program. The database can be searched using various criteria and the use of operators such as "and," "or," "begin with," "equal to," "greater than," "less than," and "contains" makes the search option flexible and efficient for selecting specific progenies. The program was originally designed for breeding several

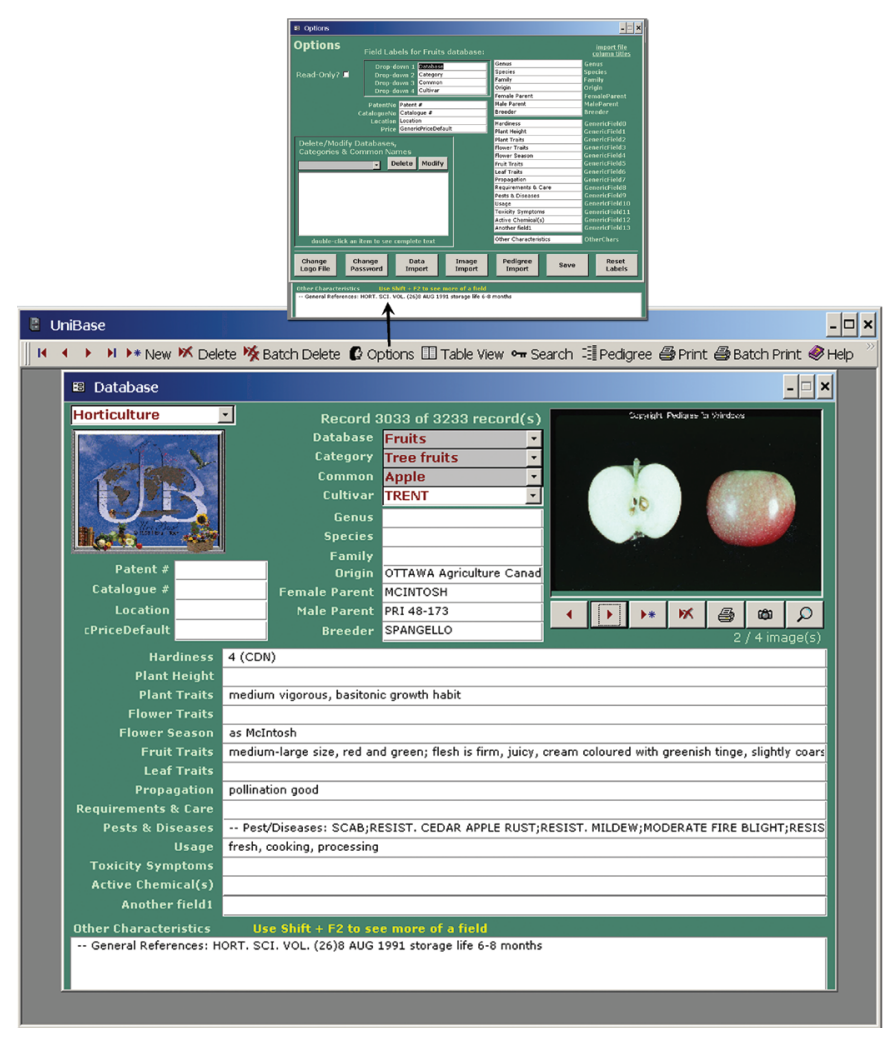

Fig 1. Main screen capture of the UniBase Program. 


\section{Cover Story}

horticultural fruit crops including strawberry and apple (Khanizadeh, 1990; Khanizadeh et al., 1991). Later, it was modified for use with for ornamentals and other fruit crops.

Since then, it has been used throughout

Canada, the United States, and Europe by many

Table 2. Available data and images with UniBase program.

\begin{tabular}{|c|c|c|c|c|}
\hline Database & Category & Common name & $\begin{array}{l}\text { No. of } \\
\text { entries }\end{array}$ & $\begin{array}{l}\text { No. of } \\
\text { images }\end{array}$ \\
\hline \multirow[t]{18}{*}{ Fruit } & Small fruits & Blackberry & 93 & 0 \\
\hline & & Blueberry & 114 & 1 \\
\hline & & Cranberry & 5 & 0 \\
\hline & & Currant & 128 & 0 \\
\hline & & Dewberry & 1 & 0 \\
\hline & & Elderberry & 2 & 0 \\
\hline & & Gooseberry & 71 & 0 \\
\hline & & Mulberry & 1 & 0 \\
\hline & & Raspberry & 338 & 0 \\
\hline & & Strawberry & 1053 & 290 \\
\hline & Tree fruits & Apple & 3000 & 1800 \\
\hline & & Apple rootstock & 47 & 0 \\
\hline & & Apricot & 133 & 0 \\
\hline & & Cherry & 104 & 0 \\
\hline & & Crab apple & 90 & 0 \\
\hline & & Peach & 828 & 0 \\
\hline & & Pear & 295 & 0 \\
\hline & & Plum & 299 & 14 \\
\hline \multirow[t]{14}{*}{ Ornamentals } & Annuals & Annuals & 2748 & 0 \\
\hline & Biennials & Biennials & 59 & 0 \\
\hline & Broadleaf & Broadleaf & & \\
\hline & Evergreen shrub & Evergreen shrub & 103 & 0 \\
\hline & Bulbs & $\begin{array}{l}\text { (Alium; Anemone; Canna; Crocus; } \\
\text { Jonquil; Jonquil-small cup; } \\
\text { Jonquil-trumpet; Darwin tulip; } \\
\text { Double early tulip Double hyacinth; } \\
\text { Double Late tulip; Fosteriana tulip; } \\
\text { French single late tulip; Freesia; } \\
\text { Fringed tulip; Fritillaria; Gladiolus; } \\
\text { Glory of the Snow; Grape hyacinth; } \\
\text { Greigii tulip; Kaufmanniana tulip; } \\
\text { Lily tulip; Parrot Tulip; Single early tulip; } \\
\text { Single hyacinth;Single late tulip; } \\
\text { Snowdrops; } \\
\text { Special bulbs; Species tulip; } \\
\text { Tassel hyacinth; Triumph tulip; }\end{array}$ & & \\
\hline & Conifers trees & Viridiflora tulip; Wood hyacinth) & 371 & 0 \\
\hline & and shrubs & and shrubs & 158 & 0 \\
\hline & Deciduous shrubs & Deciduous shrubs & 142 & 0 \\
\hline & Deciduous trees & Deciduous trees & 176 & 0 \\
\hline & $\begin{array}{l}\text { House plants } \\
\text { (flowering) }\end{array}$ & $\begin{array}{l}\text { House plants } \\
\text { (flowering) }\end{array}$ & 0 & 0 \\
\hline & House plants & House plants & & \\
\hline & (foliage plants) & (foliage plants) & 0 & 0 \\
\hline & Perennial & Perennial & 0 & 0 \\
\hline & Roses & $\begin{array}{l}\text { Climbing roses; } \\
\text { climbing roses-large flowers; } \\
\text { climbing roses-ramblers; } \\
\text { David Austin roses, English roses; } \\
\text { Explorer roses-climbing; } \\
\text { Explorer roses-shrub; } \\
\text { Explorer roses-miniature; Floribunda rose; } \\
\text { Grandiflora; Hybrid Tea; Miniature roses; } \\
\text { Miniature roses-climbers; } \\
\text { Old Garden; other series-shrub; } \\
\text { Parkland; Rugosa; Shrub soses; } \\
\text { Shrub roses/Meidiland; Species roses; } \\
\text { Subzero roses }\end{array}$ & 487 & 0 \\
\hline Poisoneous & Poisoneous & Poisoneous & & \\
\hline plants & plants & plants & 257 & 0 \\
\hline Tropical & Tropical fruits & Tropical fruits & 248 & 0 \\
\hline
\end{tabular}

Tropical Tropical fruits entry contains only the parentages to complete the pedigree of the others. No information is provided on the pedigree (Parentages) of the ornamental, poisonous, and tropical plants but the user can add it.

users. Comments and suggestions provided by previous users were incorporated into UniBase including change field name using any language, the ability to add new database, import and/or scan data and images, scan and bring the images into database or import directly from no limitations to the number of entries that can be incorporated into a database and to the number of different databases that can be created. An unlimited number of images can be stored for each entry and several graphic formats including BMP, JPEG, GIF, TIFF, etc., can be used.

UniBase is very useful for germplasm inventory and has a unique and universal structure, which can be used for horticultural fruit crops, agronomy, classification of weeds, diseases, insects, chemicals, and animals. Some information (female and male parents, origin, breeder name, year released, fruit, plant, and disease susceptibility) is presently available on certain horticultural crops (Table 2) and is available to the user.

An option has also been added to the program that allows the user to import data and images via Excel into UniBase. The software can also be installed on a server and several users can share the information or work on different databases simultaneously. The program allows the administrator to add a password that makes the database read only (for visitors) or be fully controlled by selected users.

Additional information on UniBase and the use of different windows e.g., generating "pedigree," "Option," "import data," etc., can be accessed from the authors.

\section{Literature Cited}

Bassi, D., E. Muzzi, P. Negri, and R. Selli. 1990. A computer program for record-keeping and seedling evaluation in fruit trees. HortScience 25:121.

Dowling, T.E. and X.S. Moore. 1984. A program for estimating genetic variability within and between populations. J. Hered. 75:416.

Kang, M.S. 1985. SAS program for calculating stability-variance parameters. J. Hered. 76:142-143.

Khanizadeh, S. 1990. Pedigree, Version 3.0, Registration no. 403061. Consumer and Corporate Affairs Canada, Copyright Office, Ottawa.

Khanizadeh, S., M.J. Lareau, and D. Buszard. 1991. Pedigree: A program to trace and draw pedigree records. HortScience 26:1088.

Khanizadeh, S. and M. Fanous. 1992. Mathematical indices for comparing small fruit crops for harvest time and trait similarity. HortScience 27:346-348.

Khanizadeh, S. and Shiv Prasher, 1997. Pedigree for Windows-A database program to trace pedigree and characteristics of 18 fruit crops. Acta. Hort. 439:97-99.

Khanizadeh, S., H.K. Hall, and S.O. Prasher. 2000. Pedigree and Pedigree data and image wizard: A database to trace traits, draw pedigree and view images of 37 horticultural fruits crops. Acta Hort. 525:149-152.

$\mathrm{Ng}$, T.J. 1990. Generation means analysis by microcomputer. HortScience 25:363

St. John, R.C., N. Shafer, and R.C. Woodruff. 1983. A computer analysis of the statistical significance of mutation rates. J. Hered. 74:85-87.

HortScience Vol. 39(3) June 2004 